\title{
Do Central and Eastern Europe Countries Play a Role in the Belt and Road Initiative? The Case of Chinese OFDI into the CEE-16 Countries
}

Tomasz Bieliński

Assistant Professor, Faculty of Economics, University of Gdansk, Gdansk, Poland e-mail: t.bielinski@ug.edu.pl

\section{Magdalena Markiewicz}

Assistant Professor, Faculty of Economics, University of Gdansk, Gdansk, Poland e-mail:m.markiewicz@ug.edu.pl

\section{Ewa Oziewicz}

Professor, Faculty of Economics, University of Gdansk, Gdansk, Poland e-mail: ekoeo@ug.edu.pl

\begin{abstract}
The main aim of the article was to analyze the motives behind the FDI decisions of Chinese companies' capital engagement in Central and Eastern Europe. The article examines the applicability of existing theoretical concepts towards Chinese outward foreign direct investment (OFDI). Chinese OFDI patterns have been found to be consistent with Dunning's investment development path (IDP) theory, but research shows that OFDI to CEE countries is additionally driven by specific motives different than in other regions. The study has proved that one of the major purposes is to get access to the EU common market. Additionally, data analysis has revealed that CEE countries that are not part of the EU attract proportionally more Chinese FDI than those that have easier access to EU funds.
\end{abstract}

Keywords: FDI, CEE-16, China, Belt and Road Initiative, BRI, OBOR, internationalization

JEL: F2, F21, F23, F63 


\section{Introduction}

China's economic development has been widely commented on as a uniquely Chinese way of doing things. Its long-lasting, high growth rate has brought many researchers to the point where they realize new theories concerning this path of development should be created. While replacing the centrally planned system with a more efficient, market-based one, efforts were made to improve the efficiency of state-owned enterprises (SOEs). There were two stimulators to achieve this: greater autonomy and meeting competition from the non-state, private sector. However, the dynamism of the Chinese economy was not only a consequence of the swift entry of many new, small, non-state companies but also foreign direct investments flowing into China had ample input into its development. With decades passing and the business environment changing in China and the global economy, domestic companies, state-owned as well as private, have started to seek business opportunities abroad, investing capital out of their home country. It arouses interest in the issue of whether new theories should explain the process of Chinese outward foreign direct investment (OFDI).

The objective of the paper, therefore, is to identify the motives influencing Chinese outward direct investment through a theoretical analysis of OFDI approach as well as empirical examples with the special focus on 16 Central and Eastern European countries (CEE-16). Some of them are European Union (EU) members while the others' status as non-EU countries brings different values and circumstances to the OFDI in the CEE region. Several motives are quite explicit, but not all may be categorized in a classical way and require deeper investigation.

Regarding the aim of the article, three research questions were formulated. Firstly, what are the main motives of China investing abroad and what implications arise for the applicability of existing theoretical concepts? Secondly, what is behind the Chinese OFDI, especially in Central and Eastern Europe? Are there any specific reasons, why capital from China is located in CEE? Thirdly, which host countries and industries attract Chinese FDI to the CEE-16 economies?

Owing to the vast majority of available literature concerning FDI flows into or out of the countries and the different motivations of home and host countries, this article concentrates on the OFDI of China into other countries with the emphasis on Central and Eastern Europe. Therefore, the development of OFDI is targeted across many countries through the lens of global, regional and local attitudes, particularly the Belt and Road Initiative, its goals and values. The CEE-16 countries are geographically related, but they contribute to divergent channels of economic cooperation. This enables the researchers to formulate two hypotheses.

H1: Although, in general, the Chinese outward direct investment is consistent with Dunning's investment development path (IDP) theory, Chinese OFDI in Central and Eastern European countries is additionally driven by specific motives different than in other regions. One of the major motives for Chinese OFDI in Central and Eastern European countries is to get access to the EU common market. 
H2: CEE countries that are not part of the EU attract proportionally more Chinese FDI than those that have easier access to EU funds.

As the main focus of the article is to analyze the motives behind the FDI decisions of Chinese companies' capital engagement in the CEE-16 and assess the results, it covers three main related areas. Firstly, it shows the evolution of theories concerning OFDI and its approaches towards its impact on the host country. The article reviews the integrity of the EU and CEE-16 countries within the cooperation with Chinese investors. Regardless of geographical resemblance and parallel cultural heritage, the CEE-16 countries do evolve, overcoming diverse challenges. Thirdly, it examines the significance of the volume of Chinese OFDI in specific countries and highlights their major advantages and disadvantages with regard to the domestic markets.

\section{Methods and sources}

The background of the paper was prepared on the analysis of literature studies regarding OFDI and economic relations between China and the EU. The first part of this article explains the traditional and contemporary approach to Chinese OFDI; the second part uses the available data and studies on conducting trade; the third one focuses on the CEE-16's role in investment and trade relations between China and the EU. The fourth part concentrates on investment in Poland as the most advanced country receiving Chinese OFDI. Due to the research on the effects of the Belt and Road Initiative project being in its initial stages, there are limited studies regarding the long-time horizon of analysis, and it is one of the initial approaches towards the deeper analysis of this issue. The paper was based on literature studies and market data analysis. Data on OFDI from China to the CEE-16 was based on data provided by the National Bureau of Statistics of China and the Rhodium Group.

\section{Governmental policy and the framework of Chinese OFDI}

The Chinese economy started to open up in 1978, but as far as OFDI is concerned, it was only after 2000 when it took off. This was when Zhu Rongji, the Chinese Prime Minister, was in power. The Going Global strategy he announced in 1999 and China's membership of the WTO since 2001 were the main impulses to start investing abroad. This period has been called Going Global 1.0 (China Going Global 2017, p. 3). Chinese companies were provided with a framework to find resources and export their products. The country's policy of supporting FDI has been one of the most extensive among developing countries. The last years put China at the top of the list of OFDI countries, just after the USA. In 2016 China invested directly in 7961 non-financial foreign companies from 164 countries and regions all over the world. The total accumulative investment in 2016 was USD 170.11 bn, with year-on-year growth of $44.1 \%$. Those of Chinese OFDI have been called Going Global 2.0 (China Going Global 2017, 
p. 5). The concept of Going Global 2.0 has created a more sublimated framework for Chinese OFDI to look beyond resources and markets and aim at win-win solutions, especially within Xi Jinping's Belt and Road Initiative (BRI) announced in 2013.

The aims within Going Global 2.0 were mainly to ensure a return on investment, stimulate global demand, switch to portfolio investment, and avoid dividing the political elites; meanwhile, Going Global 1.0 aimed at solving resource security, buying whole value chains, and buying majority stakes, among others (China Going Global 2017, pp. 4-5).

A kind of regularity can be noticed in China's expansion of state-owned enterprises. On the one hand, they invest in countries with natural resources, underdeveloped state institutions and risky (for conducting business) political environments. On the other hand, they seek investment possibilities in high-tech sectors, to get access to the newest technologies and find opportunities for acquiring the best, well known global brands from developed countries.

Another issue is the approach towards OFDI: while SOEs are more oriented on fulfilling the state's economic goals and expanding exports, making use of idle capacity when there is slower economic growth and providing strategic access to infrastructure, such as ports, roads, logistic hubs, etc., private companies investing abroad are more profit-oriented. For the last ten years, the authorities encouraged investors to enter sectors that could bring innovation to the Chinese economy. So far, the innovative sectors have been mainly in private hands. The big SOEs were established in the period before the boom of technology-driven industries, and companies from modern technology sectors are mainly private (e.g., Alibaba, Baidu or Tencent). China wants its economy not to be state dominated, but with much more control by authorities than in the Western countries. The state enterprise reform in December 2017 enhances SOEs so that they can buy stakes in private companies, especially in target sectors, like technology, internet, semiconductors, high-end manufacturing and national defense (Bloomberg, 2018). This means they have more influence on decisions concerning OFDI. The authorities also stimulate private companies to buy stakes in SOEs.

Economists in China are concerned about the dynamic increase in investment abroad, which could weaken the national industry and, instead of stimulating the economy, make further sustainable economic growth more difficult. Chinese companies' investing abroad diminishes the possibilities of them locating investment in Central and Western Chinese provinces, rich in labor, but suffering from a shortage of capital (Mei 2015). However, the BRI can stimulate growth in these provinces.

\section{Remarks on the theoretical background of outward FDI}

The question above about the specifics of Chinese OFDI could be formed in a more general way, embracing developing countries investing abroad. Western researchers have perceived inflows of FDI to those countries as a natural confirmation of neoclassical theories 
about the abundance and scarcity of resources. Countries with an abundance of capital should be exporters of capital, while developing countries, lacking capital, are supposed to import it. There is at least one problem in this way of thinking: even in a developing country can one find individual private companies with enough capital to start investing abroad, and companies should enlarge their assets portfolio to stay competitive.

The majority of FDI theories relate to the OFDI of developed economies. The most widespread is the one put forward by Dunning in the early 1980s, which states that the net outward investment position (NOIP) of a country depends on its level of development counted by GDP per capita. It is called the Investment Development Path (IDP). IDP theory was later revisited several times by Dunning and Narula (Dunning, Narula 1996, pp. 1-41). According to the theoretical framework, five development stages emerge. Along these stages the ownership, internalization and locational advantages change, causing modifications in the direction of FDI - a country evolves from inward into an outward direct investor. Dunning and Narula have placed emerging economies, and China among them, in the third stage. Later, Dunning, Kim and Lin incorporated trade into the Investment Development Path, creating a parallel hypothesis called the Trade Development Path (Dunning, Kim and Lin 2001, pp. 145-154).

Many authors doubted China's ability of to move along the IDP because of different factors that impacted FDI flows, like the idiosyncratic characteristics of Chinese companies and institutional factors that might limit the considerable increase in the internationalization of Chinese firms (Kefei 2017, pp. 239-253) or Ozawa's dynamic theory of economic development and competitive advantage of countries (Ozawa 1992, p. 27-54). It explains the possibility of creating conditions in a developing country for enhancing OFDI as a consequence of super growth. However, applying IDP theory to emerging and transition economies arouses many questions and some hesitation. In fact, there are numerous factors and conditions that could cause different behavior

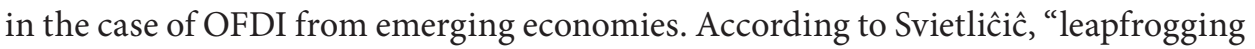
globals" in transitional economies can skip some of the stages described in the IDP theory (Svetličič 2003, p. 47-64). It could also happen to emerging economies, China among them. Buckley et al. (2007, pp. 499-518) and Wang et al. (2012, pp. 655-676) have also combined different theories to examine Chinese OFDI.

This proves hypothesis 1 that although, in general, Chinese outward direct investment is consistent with Dunning's investment development path (IDP theory), Chinese OFDI to CEE countries is additionally driven by specific motives, as there are diverse elements influencing OFDI in those countries (Dunning, Narula 1996, p. 1-41). One of them is government involvement in OFDI, demonstrated by formal agreements between the cooperating countries at the central government level, like launching the CEE $16+1$ platform.

There is much difference in the affiliation of local companies with government agencies in each of the emerging countries, as well as in the degree of state ownership. Chinese companies are nowadays encouraged to mix and exchange shares among themselves, not to mention state support in different forms for companies while go- 
ing global. One theory that is strongly connected with this problem is institutional theory and government steward logic. According to classical FDI theory, the motivations to engage in FDI are grouped into four broad categories: natural resource-seeking, market-seeking, efficiency-seeking and strategic assets-seeking. Regarding the first one - natural resource-seeking - according to Luo and Rui, Chinese companies were urged by the government to gain natural resources from different locations in order to support the development of the home economy (Luo, Rui 2017, p. 49-70). They named this motivation government steward logic, indicating that a company from China could be subsidized or even compelled by the government to invest in natural resources. It is easily noticed as far as Chinese infrastructural investment or seeking innovation or new technologies through OFDI are concerned. Institutional theory and government steward logic were mentioned by Kefei, who found only two variables based on the extended IDP to be robust determinants: trade openness and agglomeration effect (Kefei 2017, pp. 239-253). By contrast, he stressed the role of government policies.

Other theories that may be applied to Chinese OFDI are latecomer theory ${ }^{1}$, the springboard perspective (Luo and Tung 2018, pp. 129-152; Luo and Tung 2007, pp. 481-498), LLL (linkage-leverage-learning), the ambidexterity perspective and the global mindset perspective. Latecomer theory means that emerging economies benefit from the 'latecomer's advantage,' as technological innovation and industrial upgrading can be achieved by importing, imitating and integrating existing technologies and industries, which consequently brings savings on R\&D. An economy that makes use of its latecomer's advantage to upgrade technologically and industrially can grow faster than developed economies. Regarding the LLL strategic framework, it is not seen as "displacing microeconomic reasoning of OLI, but [is] a way of complementing the timeless insights of OLI with the strategic necessities of latecomer firms seeking to become players in the globalized economy" (Mathews 2017, pp. 769-775). Ambidexterity theory highlights the unique strategic behavior of transnational enterprises from emerging markets (Luo, Rui 2017, pp. 49-70). The global mindset perspective stresses the ability of an individual to adapt to globalization processes, to have consciousness of differences, and have the vision and power to "infect" others with the concept of internationalization (Gupta, Govindarajan 2002, pp. 116-126). While deliberating the theoretical side of Chinese OFDI, one should not forget about the CAGE distance framework (Ghemawat 2001, pp. 137-147). Following the idea of semi-globalization, Ghemawat has developed a framework based on cultural, administrative, geographical and economic distances.

Reviewing theoretical models concerning OFDI from emerging markets, and China most notably, one could draw conclusions about the motives of China investing abroad and the implications for the applicability of existing concepts. Different theories do not necessarily replace each other but explain altered aspects of the same phenomenon. Using diverse theories and their combinations to explain OFDI from emerging countries is recommended.

1 This theory was initially introduced by Veblen at the beginning of the $20^{\text {th }}$ century. 


\section{Chinese OFDI motives in the CEE-16 - the mode of entry and volume}

Chinese FDI has been undertaken in many sectors. Factors affecting investment include acquiring new technologies and recognized brands to support China's competitiveness in the transition to an advanced stage of development. One of the goals of Chinese OFDI is to find new sources of demand for products and services produced in China, in terms of excessive production capacity. OFDI enables Chinese enterprises to diversify portfolio risk, obtain stable profits and expand into new markets. Some authors have investigated factors concerning the expansion of Chinese multinational corporations in Europe, pointing to resources and organizational and institutional motives (Wang, Hong, Kafouros, Boateng 2012, pp. 425-438). Others point to a minor number of small entities making investments, which affects the achievement of economies of scale, particularly in highly competitive sectors (Wang, Wen, Han 2012, pp. 547-548).

Chinese investments in the EU are relatively low in value, despite the EU's economic importance. As far as the type of investors is concerned, the largest investments have been made as brownfield investments by large enterprises with the majority of state capital (SOE), banks and government agencies, which has prompted problems related to excessive concentration (Ebbers, Zhang 2010, pp. 188-203). Private-owned enterprises (POEs) are increasingly involved in investments. Their financial support complies with the legal restrictions regarding foreign investments and covers activities of financial institutions, development banks or funds which support BRI programs. Both SOEs and POEs are looking for opportunities to enter the EU internal market through investments in the CEE-16 region (as stated by hypothesis 1). Many Chinese companies acquiring a foreign enterprise have a so-called "light touch" approach. Taking over a company in such a way does not mean much self-sacrifice for the host company because the Chinese investor's main aim is to gain special skills, a strong brand, or other assets of the acquired enterprise.

Statistics of the National Bureau of Statistics (NBS) in Beijing provide valuable data on Chinese investments in the CEE-16. The total net overseas direct investments from China to the CEE-16 fluctuated between 2014 and 2016 at a level between USD 4,013 MM (in 2014), USD 11,348 MM (in 2015) and USD 4,117 MM (in 2016). The cumulative value of Chinese OFDI into the CEE-16 between 2014 and 2016 achieved a level of USD 19,478 MM while the value of total FDI in Europe reached a level of USD 2,717 $\mathrm{BN}$ in 2016 alone (Chart 1).

The comparison of total net overseas direct investments from China to CEE-16 with the OFDI to all European countries communicates a huge disparity. When compared to whole Europe the net OFDI to the CEE region oscillates within the band of a very low share, only $0.37-1.65 \%$ of European incoming investments between 2014 and 2016. According to NBS data, the biggest foreign direct investment values were observed in Poland and the Czech Republic; by contrast, Slovakia was characterized by one-third of the 
Czech investment value. In Hungary, it did not exceed the Slovak level, and in Lithuania, these OFDI were noticed only in 2016. Analyzing the specific total sums of Chinese OFDI to the CEE-16 between 2014 and 2016, the biggest beneficiaries were Poland (USD 9,081 MM in three years), the Czech Republic (USD 6,146 MM), Lithuania (USD 1,576 MM), Slovakia (USD 1,497 MM) and Hungary (USD 687 MM) (China Statistical Yearbook 2017), while no overseas direct investments were disclosed in the case of 5 out of the 16 countries: Albania, Bosnia and Hercegovina, Macedonia, Montenegro and Serbia.

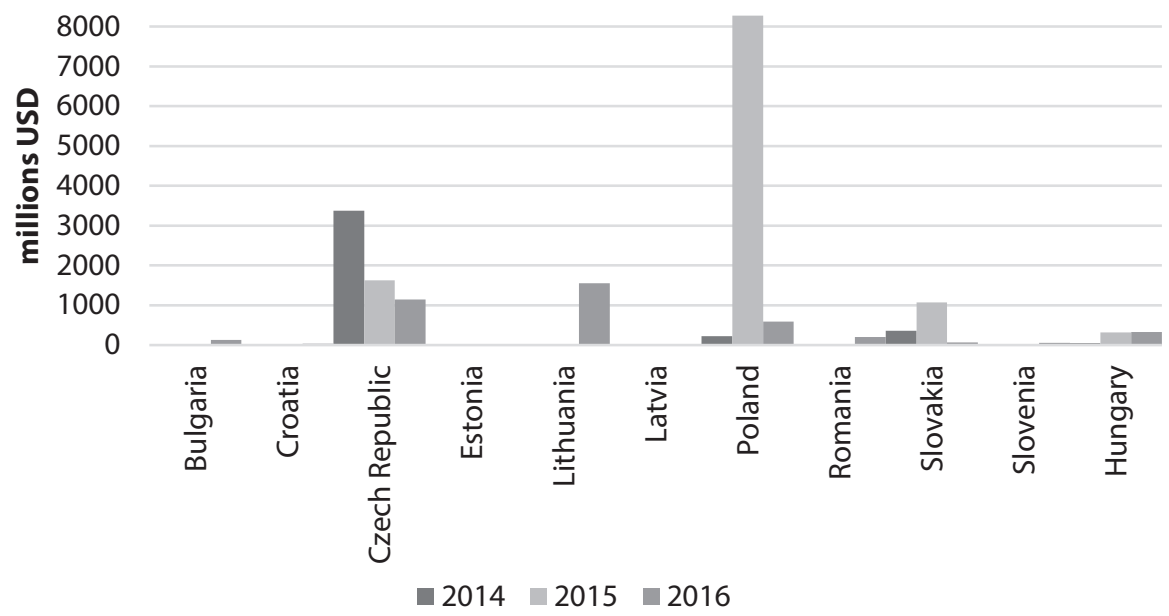

Chart 1. Net Chinese FDI value in the CEE-16 countries between 2014 and 2016 (USD MM)*

*no overseas direct investments were disclosed in the case of 5 out of the 16 countries: Albania, Bosnia and Hercegovina, Macedonia, Montenegro and Serbia

Source: own elaboration based on China Statistical Yearbook 2017, National Bureau of Statistics, http:// www.stats.gov.cn/english/statisticaldata/annualdata/ (accessed: 14.09.2018).

The other perspective comes from contract project investments analysis. The majority of investment flows in non-EU countries are observed in the form of contracts made by large Chinese enterprises. Their presence in the CEE-16 is even more intensive than OFDI when compared to all European countries. In Table 1, the value of Chinese contractual projects in the CEE-16 countries is identified. The total value of such Chinese investment in the CEE-16 in 2015 equaled 13.85\%, and in 2016 it was at the level of $11.1 \%$ of those in Europe as a whole. The largest amount was held by non-EU countries, i.e., Albania, Bosnia and Herzegovina, Macedonia, Serbia, and Montenegro (in total: USD 143,196 MM in 2015-2016).

At the same time, $11 \mathrm{EU}$ members of the CEE-16 signed contractual projects with a total value of USD 67,160 MM, which means $46.9 \%$ of the value of non-EU members' contracts. Within the EU, the largest beneficiaries of contractual projects were Romania, the Czech Republic, Poland and Bulgaria (USD 60,432 MM in total). In 2016, the value of contractual projects in the CEE-16 reached USD 88,716 MM, while contracts in Europe as a whole reached USD 798,582 MM. 
Chinese investors invest in non-EU countries (Albania, Serbia, Macedonia and Bosnia and Herzegovina) more than in EU countries, mainly Poland, the Czech Republic, Bulgaria and Hungary. It proves hypothesis 2. Infrastructure projects, whose number and value are higher than the number of foreign direct investments, have been implemented mainly in the Balkans, aimed at improving the transport of Chinese goods from the port of Piraeus in Greece to the countries of Western Europe.

Table 1. The value of contractual projects in the CEE-16 countries (non-EU and EU) in 2015-2016 (USD MM)*

\begin{tabular}{|l|r|r|l|r|r|}
\hline $\begin{array}{c}\text { Country (EU members } \\
\text { from the CEE=16) }\end{array}$ & 2015 & 2016 & $\begin{array}{c}\text { Country (non-EU countries } \\
\text { from CEE-16) }\end{array}$ & 2015 & 2016 \\
\hline Bulgaria & 3041 & 7758 & Albania & 18809 & 896 \\
\hline Croatia & 213 & 471 & Bosnia and Hercegovina & 19410 & 1724 \\
\hline Czech Republic & 7754 & 5698 & Macedonia & 36906 & 20958 \\
\hline Estonia & 0 & 497 & Montenegro & 3107 & 3696 \\
\hline Hungary & 0 & 3883 & Serbia & 19801 & 17889 \\
\hline Lithuania & 399 & 287 & Total volume (B) & 98033 & 45163 \\
\hline Latvia & 96 & 0 & & & \\
\hline Poland & 6873 & 5814 & & 2015 & 2016 \\
\hline Romania & 5037 & 18457 & CEE-16 total volume (A+B) & 121640 & 88716 \\
\hline Slovenia & 194 & 688 & Europe & 878279 & 798582 \\
\hline Total volume (A) & 23607 & 43553 & CEE-16 (A+B)/Europe (\%) & 13.85 & 11.11 \\
\hline
\end{tabular}

*data are demonstrated for 10 out of 11 EU members for the CEE16 countries; no contractual projects were disclosed in 2015 and 2016 in Slovakia.

Source: own elaboration based on China Statistical Yearbook (2017).

The reason for using the mode of contract projects, apart from logistical aims, lies in funding the investment. China has offered a very special way of financing, that, in fact, is not competitive for EU members, with the EU funds available to them. The Chinese financial proposal is not adequate for the developmental need of the EU-11. So far, the financing model offered by China is based on loans. An important element is the condition of granting the loan - a sovereign guarantee of repayment given by a host government in case of problems on the part of a local company engaged in the project. It minimizes the risk of Chinese investors and promotes Chinese contractors, workers and technology, in fact, favoring Chinese companies. This is a way of solving Chinese problems with overcapacity in the construction sector but it also allows China to sell concrete, steel and other materials to the host countries involved in the infrastructural projects.

The EU member countries have parallel access to EU funds. Legal ownership of the infrastructural objects after they are finished is a concern. In fact, it was one of the reasons for Poland rejecting membership of the Sino-CEE Fund created in 2017. After many signals from the EU-11, the Chinese authorities are trying to remodel this way of financing infrastructural projects. This observation is consistent with hypothesis 1 . 
Concerning the value of exports from the CEE-16 to China and imports from China to the CEE-16, data retrieved for 2016 gave some crucial answers to our investigations. The average ratio of imports from China to the value of exports to China proved the asymmetry, establishing a relationship at the average level of 3.8053, while in Europe it was much smaller: 1.35 (China Statistical Yearbook 2017). The countries with the highest relationship of imports to exports connecting China with the CEE-16 region were Latvia, Lithuania, Croatia, Poland, Slovenia and Estonia. They were all characterized as EU members, and all except Poland were small countries with limited natural resources. The leader of the balanced ratio of imports from exports to China was Slovakia, with a 1.19 ratio followed by Bosnia and Hercegovina, Hungary and Bulgaria, Macedonia. All these countries did not exceed a ratio of 2.0 in 2016. If we consider the volume of exports to China, the highest level was reached by Hungary (USD 3,464 MM) and the Czech Republic (USD 2,952 MM) (China Statistical Yearbook 2017). The main importer from China in the CEE-16 in 2016 was Poland (USD 15,100 MM), then the Czech Republic, followed by Romania, Slovakia and Slovenia.

The visible and huge negative balance in trade with China, however, is compensated by the exchange with other countries, e.g., in 2015, exports from Poland prevailed over imports into the country. It is due to the global value chains. An example may be the bilateral trade between Poland and Germany: more than a quarter of exports from Poland go to Germany, and some of the Polish components are later used in German machines sold to China. The aim of Polish and other CEE-16 companies at that juncture should be promoted in the value chains. Comparing the value of CEE-16 imports with all European countries, the result is only $11.22 \%$. The contribution of Polish imports to the import value of all CEE-16 countries is $34.50 \%$ and to all European countries 3.87\%. On the example of the 2016 study, we may positively evaluate the tiny significance (only 1.20\%) of the exports and slightly higher of the import (3.87\%) determined by CEE-16 countries with China from the European perspective.

It should be noted that from China's point of view, European Union countries are a source of high-tech goods and services, which is important in the context of developing transport networks, construction and infrastructure (Huang, 2016, pp. 314-321). This is consistent with the observation of specific motives not explained only by the resource or institutional approaches (Wang, Hong, Kafouros, Boateng 2012, pp. 425-438). The "infrastructure building" attitude provides a background for the spreading of trade networks across Europe, supporting hypothesis 1. Investments in the CEE-16 countries were made mainly in the industrial sector (e.g., the chemical, transport and energy sectors). Chinese OFDI related to the chemical sector included transactions with a total value of approx. EUR 1.55 BN, like Wanhua Industrial in Hungary. In the area of transport, examples are China Communication Construction in Serbia and Poland, Guangxi Liu Gong Machinery in Poland, Shandong Gaosu in Serbia, the acquisition of a Hungarian electric car factory by Beijing WKW and electric bus factories by BYD, and in Bulgaria - train factories by CRRC. The Chinese 
OFDI to the power engineering industry covers Dongfang Electric in Bosnia and Herzegovina, Sinomach in Serbia, and China Power Investment and China Energy Engineering in Poland (Rhodium Group 2017a pp. 7-8 and 2017b, pp. 5-7).

\section{Chinese OFDI in Poland - empirical examples}

Polish-Chinese trade relations are quite underdeveloped. Poland is not a significant trading partner of China, but when the 16 countries of Central and Eastern Europe are treated as a group, it is of substantial commercial importance. Chinese investors are present in Poland in the steel industry (Liu Gong purchased the construction machinery section of Huta Stalowa Wola), the food industry (Animex was taken over in 2013 by the WH Group), and the automotive industry (two Polish factories of the Delphi car parts group were taken over by Beijing West Industries). The majority of Chinese enterprises operating in Poland are small entities.

In June 2016, the Presidents of Poland and China, Andrzej Duda and Xi Jinping, signed a joint statement on the establishment of a comprehensive strategic partnership between their countries. Three months later, China Everbright International Limited bought a majority stake in Polish Novago from Abris Capital Partners, one of the largest entities in the waste processing industry in Poland, for EUR 123 MM (PAP 2018a). This company was not bought to acquire European technology. On the contrary, Chen Xiaoping, CEO of Everbright International said that the company plan is to "promote the application of Everbright International's advanced technologies in environmental protection, renewable energy and equipment manufacturing in the environmental sector of Central and Eastern Europe." In the official press release, China Everbright International mentioned: “The acquisition marks the beginning of the Group's foray into the European waste treatment industry" (Everbright International 2016). This statement is consistent with hypothesis 1 .

The Polish authorities are trying to encourage Chinese partners to treat Poland not only as a place for acquisitions but also greenfield investments. However, as the local market may not be considered very attractive for Chinese companies, politicians openly advertise Poland as a gateway to the EU (PAP 2018c). As Poland is located near the largest European market, Germany, Chinese investors are interested in buying warehouse assets. In 2017, China Investment Corporation purchased a Logicor warehouse portfolio worth USD 15 BN. As many as 28 of the 43 properties bought are sites in Poland. Their total area is about $900,000 \mathrm{~m} 2$, and the total value is almost USD $640 \mathrm{MM}$ (ISBnews 2018).

The largest Chinese greenfield investment in Poland up to the end of 2018 was a USD 42 MM Suzhou Chunxing warehouse, logistics and prototyping facility in Gdańsk. Chinese companies are not interested in Poland itself, but they treat it as an access point for wealthier European markets. According to Steve Sun, Suzhou Chunxing's head of sales and marketing for Europe: "Geographical location, investment climate, 
access to local human resources - these were the most important factors determining the choice of location for our plant. Due to the proximity of our key partners from Western Europe, Central and Eastern Europe is an extremely convenient place to carry out investments. In addition, the port in Gdańsk, with direct sea connections to China and convenient road connections, is a competitive advantage over other regions" (Kiewlicz 2018). For similar reasons, in 2015, China International Marine Containers started to operate a semi-trailer factory in Gdynia - CIMC Trailer Poland, investing USD 3.5 MM (Dzwonnik 2018). The majority of parts are transported to the nearby port, but to avoid paying tariffs for importing vehicles to the EU, some of the production processes occur in Poland (40ton 2018).

Another USD 45 MM greenfield investment is planned in Wałbrzych Special Economic Zone, assisted by the Polish Investment and Trade Agency; it was prepared by the Ministry of Energy. Chinese company Zhangjiagang Guotai Huarong Chemical New Material (GTHR) is going to build one of the largest electrolyte factories in Europe for lithium-ion batteries, which are necessary for electric vehicles. Although the Polish market for electric vehicles is relatively small in comparison to other EU markets, the company has already bought the land necessary for the construction of the production plant (Kalwasiński 2018) and aims to sell its products in the EU market. According to the European Association of Vehicle Manufacturers, in the first quarter of 2018, 69,898 passenger EVs were registered in the European Union. This also proves that hypothesis 1 is correct.

In 2012, the Liugong company took over part of the company Huta Stalowa Wola, the largest producer of bulldozers and loaders in Poland. The value of the transaction was PLN 290 MM (Lonczak 2018). In September 2017, Liugong Dressta Machinery opened a research and development center, a regional distribution center for spare parts, and a new production line for excavators and loaders in Stalowa Wola. The company also moved its European headquarters from Amsterdam to Warsaw due to the important position of Poland on the New Silk Road map and its political, geographical and economic-trade resources (PAP 2018b). According to the company, the value of capital expenditures in the Stalowa Wola plant, including the opening of the research center and the launch of the production line, amounted to approximately USD 100 MM.

\section{Conclusions}

Regarding the questions which formed the background and inspiration for this article, the motives behind China investing abroad and the applicability of existing theoretical concepts towards it were widely analyzed. Chinese OFDI directed to the CEE-16 countries diverge when it applies to the resources and capabilities of the host countries. Additionally, the CEE $16+1$ agreement allows highly advanced and cross-country projects to be built, which all the countries might participate in. One of the specific motives is to gain access to the European market, which is achievable with the 
very high volume of capital flows into infrastructure projects, railway routes, logistic hubs and strategic industries. The CEE-16 region is, in a way, a platform to the European Union, but it also includes a very prospective market. The countries that attract Chinese FDI most are Poland, the Czech Republic, Slovakia, Lithuania and Hungary, if we consider net FDI. In terms of contractual projects, the most appealing destinations are Albania, Bosnia and Herzegovina, Montenegro, Macedonia and Serbia.

Hypothesis 1 was verified completely. It stated that although, in general, Chinese outward direct investment is consistent with Dunning's investment development path (IDP) theory, Chinese OFDI to CEE countries is additionally driven by specific motives different than in other regions. However, IDP theory was successfully confirmed in the context of the article. There are numerous factors that cause different behavior in the case of OFDI from China, which may be enumerated by what Svietliĉiĉ termed "leapfrogging globals" - transitional economies that are able to skip some of the stages described in the IDP theory. Researchers have come to the conclusion that the IDP should be extended, as there are more elements that influence OFDI from emerging economies, like government involvement in OFDI, which fits the Chinese BRI. The other approach to OFDI includes LLL, the global mindset perspective and ambidexterity theory.

Moreover, affirming that one of the major motives for Chinese OFDI in CEE countries is to get access to the EU common market, which supports hypothesis 1 , the division of some parts of the analysis towards EU and non-EU countries should be indicated. Taking into consideration the divergence in the mode of entry and models of funding sources, the investment is observed in two different ways: first, loans granted with sovereign guarantees in non-EU countries and second, connected with the use of EU funds by the host country of investment. The EU members have parallel access to the EU market and funds, and it determines their attitude to participating in common infrastructural investments. Building infrastructure objects and investing in transportation corridors, like railways, hubs, and ports, is a way to access all European countries. Such expressions of intention are included in the official speeches of central administration and entrepreneurs, which makes this observation consistent with hypothesis 1 .

Hypothesis 2 was also positively verified. Indeed, CEE countries that are not part of the EU attract proportionally more Chinese FDI than those that have easier access to EU funds, but it is mainly explained by the huge volumes of contract projects which are implemented in the non-EU countries. The analysis of export and import volumes along with net FDI did not indicate that non-EU countries are the main beneficiaries. The opposite is true when it comes to contractual projects, where the largest amount was held by non-EU countries, i.e., Albania, Bosnia and Herzegovina, Macedonia and Serbia, and Montenegro.

For China, the $16+1$ initiative is a source of knowledge about the region, investment conditions and plans, which is of great importance in the implementation of the BRI. In turn, the CEE-16 countries use this cooperation formula to mark their interests and develop bilateral relations with China. 


\section{References}

40ton (2018), Chińska naczepa, lecz montowana w Polsce - CIMC pokazał się na targach, a nawet zdobył tam nagrodę, 2017, https:/40ton.net/chinska-naczepa-montowana-polsce-cimc-pokazal-sie-targach-a-nawet-zdobyl-nagrode/ (accessed: 18.08.2018).

Bloomberg (2018), China's Companies on Notice: State Preparing to Take Stakes, "Bloomberg News", 17 January 2018, https:/Bloomberg News (accessed: 5.05.2018).

Buckley, P.J., Clegg, L.J., Cross, A.R., Liu, X., Voss, H., Zheng, P. (2007), The determinants of Chinese outward foreign direct investment, "Journal of International Business Studies", No. 38.

China Going Global (2017), China Going Global - between ambition and capacity, "China Policy", Beijing.

China Statistical Yearbook (2017), National Bureau of Statistics of China, http://www. stats.gov.cn/english/statisticaldata/annualdata/ (accessed: 14.09.2018).

Dunning, J.H., Kim, C-S., Lin, J-D. (2001), Incorporating Trade into the Investment Development Path: A Case Study of Korea and Taiwan, "Oxford Development Studies", Vol. 29, No. 2.

Dunning, J.H., Narula, R. (1996), The Investment Development Path Revisited: Some emerging issues, [in:] Dunning, J.H., Narula, R. (eds.), Foreign Direct Investment and Governments: Catalysts for economic restructuring, Routledge, London and New York.

Dzwonnik, M. (2018), Chiński gigant zainwestował w Gdyni 3,5 mln dol. A to nie koniec, 2016, http://wyborcza.pl/7,87648,20482467,chinski-gigant-zainwestowal-w-gdyni-3-5-mln-dol-a-to-nie.html (accessed: 18.08.2018).

Ebbers, H., Zhang, J. (2010), Chinese Investments in the EU, "Eastern Journal of European Studies", Vol. 1, Issue. 2, December.

Everbright International (2016), Everbright International Completes Acquisition of NOVAGO, https://www.ebchinaintl.com/en/ir/press_content.php?id=p160831 (accessed: 8.07.2018).

Ghemawat, P. (2001), Distance Still Matters. The Hard Reality of Global Expansion, "Harvard Business Review", Vol. 79, No. 8.

Gupta, A.K., Govindarajan, V. (2002), Cultivating a global mindset. "Academy of Management Executive", No. 16 (1).

Huang, Y. (2016), Understanding China's Belt \& Road Initiative: Motivation, framework and assessment, "China Economic Review", No. 40.

ISBnews (2018), Polska wśród 20 najważniejszych krajów dla chińskich inwestycji, https://businessinsider.com.pl/finanse/inwestowanie/gdzie-inwestuja-chinczycy-inwestycje-z-chin-w-polsce/0250kmt (accessed: 12.08.2018).

Kalwasiński, M. (2018), Chińczycy wybuduja fabrykę w Polsce, https://www.bankier. pl/wiadomosc/ Chinczycy-wybuduja-fabryke-w-Polsce-7593342.html (accessed: 21.08.2018).

Kefei, Y. (2017), What Drives Outward FDI of China? A Regional Analysis, "The Journal of Developing Areas", Vol. 51, No. 2, Spring 2017.

Kiewlicz, R. (2018), Chińska Grupa Chunxing otwiera prototypownię w Gdańsku, https://biznes.trojmiasto.pl/Chinska-Grupa-Chunxing-otwiera-prototypownie-w-Gdansku-n103142.html (accessed: 15.08.2018). 
Lonczak, J. (2018), Chińczycy już w cywilnej części Huty Stalowa Wola, http://www. nowiny24.pl/strefa-biznesu/wiadomosci/z-regionu/a/chinczycy-juz-w-cywilnej-czesci-huty-stalowa-wola,10208044/ (accessed: 23.08.2018).

Luo, Y., Rui, H. (2017), An Ambidexterity Perspective Toward Multinational Enterprises from Emerging Economies, "Academy of Management Perspectives", Vol. 23, No. 4, 30 November 2017.

Luo, Y., Tung, R. (2007), International expansion of emerging market enterprises: A springboard perspective, "Journal of International Business Studies", No. 38 (4).

Luo, Y., Tung, R. (2018), A general theory of springboard MNEs. "Journal of International Business Studies", No. 49 (2).

Mathews, J.A. (2017), Dragon multinationals powered by linkage, leverage and learning: A review and development, "Asia Pacific Journal of Management", Vol. 34, Issue 4, December 2017.

Mei, X. (2015), The Price of Good Investment. Are Chinese investors buying European companies at low costs? "Beijing Review" No. 27, July 2.

Ozawa, T. (1992), Foreign direct investment and economic development, "Transnational Corporations", Vol. I, No. 1., February 1992.

PAP (2018a), China Everbright International przejęła za 123 mln zł Novago w Mławie, 2016, http://budownictwo.wnp.pl/china-everbright-international-przejela-za-123-mln-zl-novago-w-mlawie,280007_1_0_0.html (accessed: 12.09.2018).

PAP (2018b), Liugong otworzył w Stalowej Woli nowe inwestycje, 2017, http://hutnictwo. wnp.pl/liugong-otworzyl-w-stalowej-woli-nowe-inwestycje,307300_1_0_0.html (accessed: 27.08.2018).

PAP (2018c), President Duda hopes Poland will become China's gateway to Europe, http://www.president.pl/en/news/art,191,president-duda-hopes-poland-will-become-chinas-gateway-to-europe.html (accessed: 8.08.2018).

Rhodium Group (2017a), EU-China FDI Monitor, 2Q 2017.

Rhodium Group (2017b), EU-China FDI Monitor, 4Q2016 Update: Public Version, Foreign Direct Investment in China, Rhodium Group, January 2017.

Svetličič, M. (2003), Theoretical context of outward foreign direct investment from transition economies, [in:] Svetličič, M. and Rojec, M. (eds.), Facilitating transition by internationalization: Outward direct investment from European economies in transition Ashgate, Aldershot.

Wang, C., Hong, J., Kafouros, M., Boateng, A. (2012), What drives outward FDI of Chinese firms? Testing the explanatory power of three theoretical frameworks, "International Business Review", Elsevier, Vol. 21 (3).

Wang, C., Hong, J., Kafouros, M., Wright, M. (2012), Exploring the Role of Government Involvement in Outward FDI from Emerging Economies, "Journal of International Business Studies", No. 43 (7). September 2012.

Wang, C., Wen, Y., Han, F. (2012), Study on China's outward FDI, "Procedia Environmental Sciences", No. 12. 


\section{Streszczenie}

\section{Rola krajów Europy Środkowej i Wschodniej w Inicjatywie Pasa i Szlaku - determinanty chińskich inwestycji bezpośrednich w krajach CEE-16}

Głównym celem artykułu jest analiza motywów dotyczących decyzji o zaangażowaniu kapitałowym chińskich spółek w Europie Środkowej i Wschodniej (EŚW). W artykule poddano analizie użyteczność istniejących koncepcji teoretycznych do wyjaśnienia uwarunkowań chińskich zagranicznych inwestycji bezpośrednich (ZIB). Decyzje chińskich podmiotów okazały się zgodne z teorią rozwoju inwestycji Dunninga (IDP), ale badania dowiodły także, że motywy ZIB są inne dla krajów regionu Europy Środkowej i Wschodniej niż w pozostałych regionach. Badanie wykazało, że jednym z głównych celów inwestycji w tym regionie jest uzyskanie dostępu do wspólnego rynku UE. Dodatkowo analiza danych ujawniła, że kraje EŚW, które nie są częścią UE, przyciągają proporcjonalnie więcej chińskich ZIB niż te, które mają łatwiejszy dostęp do funduszy UE.

Słowa kluczowe: zagraniczne inwestycje bezpośrednie, EŚW, CEE-16, Chiny, Jeden Pas Jedna Droga, Inicjatywa Pasa i Szlaku, Jedwabny Szlak 